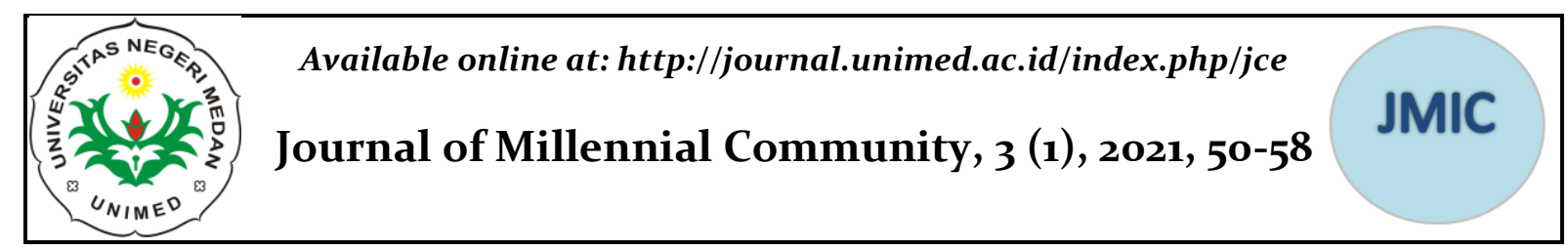

\title{
Strategi Pendidik Paud Dalam Mengembangkan Kreativitas Anak Usia 4 - 5 Tahun Di PAUD Pelita Hidup Medan Denai
}

\author{
Anifah $^{1}$, Priscillia Octavia Marpaung ${ }^{2}$, Vidya Dwi Amalia Zati ${ }^{3}$ \\ Program Studi Pendidikan Luar Sekolah, Universitas Negeri Medan \\ Email : anifah.pilcan@gmail.com
}

\begin{abstract}
$\underline{\text { Abstrak }}$
Penelitian ini bertujuan untuk mengetahui strategi pendidik PAUD dalam mengembangkan kreatifitas anak usia 4-5 Tahun di PAUD Pelita Hidup Medan Denai. Jenis penelitian yang digunakan adalah penelitian deskriptif dengan pendekatan kualitatif, dengan subjek penelitian sebanyak 3 pendidik antara lain kepala Sekolah yang merangkap sebagai pendidik dan 2 pendidik. Teknik pengumpulan data penelitian ini dengan menggunakan teknik observasi, wawancara, dan dokumentasi. Analisis data yang digunakan yaitu: reduksi data, penyajian data, penerikan kesimpulan dan verifikasi. Hasil penelitian menunjukkan bahwa pelaksanaan penerapan strategi mengajar pendidik di PAUD Pelita Hidup Medan Denai dalam mengembangkan kreativitas anak dini sudah baik. Hal ini didasarkan pada kenyataan bahwa ini dari perubahan pembelajaran,pengembangan dan mutu dan pengetahuan pendidik tergantung pada kualitas dan tingkat kemampuan, dan itu semua dapat terwujud apabila strategi mengajar pendidik diterapkan dan dikembangkan dengan baik dalam proses kegiatan belajar mengajar..
\end{abstract}

Kata Kunci : PAUD, strategi, kreativitas

\begin{abstract}
$\underline{\text { Abstract }}$
This study aims to determine the strategy of PAUD educators in developing the creativity of children aged 4-5 years at PAUD Pelita Hidup Medan Denai. The type of research used is descriptive research with a qualitative approach, with research subjects as many as 3 educators between other school principals who double as educators and 2 educators. The data collection technique of this research is using observation, interview, and documentation techniques. The data analysis used are: data reduction, data presentation, drawing conclusions and levers. The results showed that the implementation of teaching strategies for educators at PAUD Pelita Hidup Medan Denai in developing early childhood creativity was good. This is based on the fact that this changes from learning, development and knowledge of educators depending on the quality and level of ability, and it can all be realized if teaching and learning strategies are implemented and developed properly in the learning process.
\end{abstract}

Keywords: Early childhood, strategy, creativity

\section{PENDAHULUAN}

Usia dini merupakan awal bagi pertumbuhan dan perkembangan anak. Hal itu akan membawa dampak sepanjang kehidupan anak. Selanjutnya pendidikan anak usia dini didirikan sebagai usaha mengembangkan kepribadian anak didik dalam rangka menjembatani pendidikan dalam keluarga dan pendidikan sekolah yang bertujuan untuk membantu meletakkan dasar ke arah perkembangan sikap, pengetahuan, keterampilan, dan kreativitas yang diperlukan oleh anak didik dalam menyesuaikan diri dengan 
lingkungan dan untuk pertumbuhan dan perkembangan selanjutnya.

Pendidikan mutlak diperlukan dalam hidup sepanjang hayat mengingat tingkat kebutuhan dan persaingan hidup yang semakin tinggi. Tanpa pendidikan sama sekali mustahil suatu kelompok manusia dapat dilihat perkembangan ilmu pengetahuan dan teknologi dalam dunia pendidikan dengan

ditemukannya berbagai metode dan strategi pengajaran dalam dunia pendidikan dan untuk mendukung berlangsungnya proses belajar. Pendidikan anak usia dini adalah suatu proses pembinaan tumbuh kembang anak usia lahir hingga enam tahun secara menyeluruh yang mencakup aspek fisik dan nonfisik dengan memberikan rangsangan bagi perkembangan jasmani, rohani (moral dan spiritual), motorik, akal pikiran, emosional dan sosial yang tepat agar anak tumbuh dan berkembang secara optimal (Mansur, 2007 : 88).

Dalam Undang - Undang Nomor 20 Tahun 2003 Tentang Sistem Pendidikan Nasional Bab I ayat 14 menyatakan: Pendidikan anak usia dini adalah upaya pembinaan yang ditujukan bagi anak sejak lahir sampai dengan usia enam tahun yang dilakukan melalui pemberi rangsangan pendidikan untuk membantu pertumbuhan dan perkembangan jasmani dan rohani anak memili kesiapan dalam memasuki pendidikan lebih lanjut (Danar Santi, 2009 : 7). Menurut data Dinas Pendidikan Kota Medan, pada tahun 2016 jumlah PAUD di kota Medan adalah 349 Sekolah yang terdapat dalam 21 kecamatan. Berdasarkan hasil observasi tersebut menunjukkan bahwa tingkat kreativitas anak uasia 4 - 5 tahun PAUD yang ada di kota Medan sekitar 69\%. Lalu observasi yang saya lakukan di PAUD Pelita Hidup Medan Denai pada usia anak 4 - 5 tahun menunjukkan bahwa 13 peserta didik kurang kreatif (46\%) sedangkan 15 peserta didik menunjukkan kreativitas yang mulai berkembang (54\%). Dan pada tahun 2017 perkembangan kreativitas anak usia dini di PAUD Pelita Hidup semakin Page|51 meningkat menjadi 21 peserta didik $(75 \%)$ dan 7 peserta didik lagi masih kurang kreatif (25\%).

Secara alamiah pertumbuhan dan perkembangan anak berbeda-beda, baik dalam bakat, minat, kreativitas, kematangan emosi, kepribadian, keadaan jasmani, dan sosialnya. Selain itu, setiap anak mmiliki kemampuan tak terbatas dalam belajar yang inheren (telah ada) dalam dirinya untuk dapat berpikir kreatif dan produktif. Anak akan beraktivitas sesuai dengan minat dan potensi yang dimiliki dirinya, pengembangan kreativitas anak harus diberikan stimulasi dari mulai usia dini, sehingga anak akan terasa untuk berpikir kreatif, karena dengan kreativitaslah memungkinkan menjadi berkualitas dan suprise dalam hidupnya. Anak akan melihat masalah dari berbagai sudut pandang, mampu menghasilkan karya yang berbeda dari yang sudah ada sebelumnya.

Kreativitas sangat penting untuk dikembangkan sejak usia dini, seperti yang dikemukakan oleh Munandar (1992 : 46), bahwa : "Kreativitas yang memungkinkan manusia meningkatkan kualitas hidupnya. Dalam era pembangunan ini tidak dapat dipungkiri bahwa kesejahteraan dan kejayaan masyarakat dan negara bergantung pada sumbangan kreatif, berupa ide - ide baru, penemuan - penemuan baru, teknologi baru dari anggota masyarakatnya”. Untuk mencapai hal itu, perlulah sikap dan perilaku kreatif dipupuk sejak dini, agar anakdidik kelak tidak hanya menjadi konsumen pengetahuan baru dan pencari 
kerja, tetapi mampu menciptakan pekerjaan baru.

Berkenaan dengan kreativitas di Indonesia, Supriadi (1994) telah mengemukakan hasil studi yang dilakukan oleh Jellen dan Urban pada Tahun 1987 berkenaan dengan tingkat kreativitas anak usia dini di berbagai Negara, termasuk di Indonesia. Data menunjukkan bahwa Indonesia menempati posisi terendah dibandingkan 8 negara lainnya, jauh di bawah Filipina, Amerika Serikat, Inggris dan Jerman, bahkan dibawah negara India, Kameru, dan Zulu. Apa yang menyebabkan fenomena ini? Banyak faktor yang diperkirakan menjadi penyebab rendahnya kreativitas di Indonesia. Beberapa faktor tersebut diantaranya pola asuh orangtua yang cenderung otoriter serta sistem

pendidikan yang kurang mendukung.

Sistem pendidikan saat ini hanya menonjolkan kemampuan akademik saja seperti kemampuan membaca dan berhitung. Orangtua atau pendidik merasa bangga bila anak didiknya mampu membaca dan berhitung dengan lancar sehingga nilai moral dan emosi tak lagi penting. Tuntutan orangtua dan syarat untuk memasuki jenjang pendidikan yang lebih tinggi menjadi dalih yang mengkehendaki anak pandai membaca dan berhitung. Seorang pendidik hanya menekankan metode dan strategi pembelajaran yang mengasah kecerdasan otak kiri saja yaitu membaca dan berhitung. Penggunaan metode yang statis membuat anak bosan akibatnya otak kanan yang berfungsi sebagai pengembangan kreativitas anak tidak dapat berkembangan secara optimal.

Masa anak usia 4 - 5 tahun merupakan masa paling penting karena merupakan pembentukan pondasi kepribadian yang menentukan pengalaman anak selanjutnya. Karakteristik anak usia dini menjadi mutlak dipahami untuk memiliki generasi yang mampu mengembangkan diri secara optimal menginat penting usia tersebut. Mengembangkan kreativitas Page|52 anak memerlukan peran penting pendidik hal ini secara umum sudah banyak dipahami. Anak kreatif memuaskan rasa keingintahuannya melalui berbagai cara bereksplorasi, bereksperimen, dan banyak mengajukan pertanyaan pada orang lain. Suratno (2005 : 19) menjelaskan anak kreatif dan cerdas tidak terbentuk dengan sendirinya melainkan perlu mengarah salah satunya dengan memberi kegiatan yang dapat mengembangkan kreativitas anak. Fenomena yang ada selama ini kreativitas yang dimiliki oleh masyarakat pada umumnya masih rendah. Hal ini dapat diketahui dengan masih banyaknya orang - orang yang belum mampu menghasilkan karyanya sendiri, mereka masih meniru karya milik orang lain. Keadaan tersebut disebabkan karena kurangnya pengembangan kreativitas sejak usia dini.

Tahap perkembangan kreativitas anak usia 4 - 5 Tahun Menurut Rachmawati dan Kurniati (2011 : 15) yaitu: Terbuka terhadap pengalaman baru, fleksibel dalam berpikir dan merespon, bebas dalam menyatakan pendapat dan perasaan, menghargai fantasi, tertarik pada kegiatan-kegiatan kreatif, mempunyai pendapat sendiri dan tidak terpengaruh oleh orang lain, mempunyai rasa ingin tahu yang besar, berani mengambil resiko yang diperhitungkan, percaya diri dan mandiri, memiliki tanggung jawab dan komitmen dalam tugas, tekun dan tidak mudah bosan, tidak kehabisan akal dalam memecahkan masalah, kaya akan inisiatif, peka terhadap situasi lingkungan, memiliki 
citra diri dan stabilitas emosi yang baik, tertarik kepada hal- hal yang abstrak, kompleks, holistik dan mengandung teka - teki, memiliki gagasan yang orisinal, mempunyai minat yang luas, kritis terhadap pendapat orang lain, senang mengajukan pertanyaan yang baik.

Untuk mengembangkan kreativitas anak usia dini tersebut dibutuhkan pendidik yang profesional untuk menjadikan anak yang kreatif, maka pendidik harus mempunyai strategistrategi yang baik dan tidak membosankan dalam proses pembelajaran agar mampu mengembangkan pengetahuan dan keterampilan. Salah satu langkah untuk memiliki strategi itu ialah harus menguasai teknik - teknik penyajian atau metode mengajar yang mana teknik penyajian merupakan suatu pengetahuan tentang cara - cara mengajar yang dipergunakan pendidik agar materi atau pesan yang disampaikan pendidik dapat diterima dengan baik dalam pembuatan media yang dijadikan alat utama dalam pembelajaran anak. Alat permainan media yang dimaksud tentu harus dapat mengembangkan kemampuan dasar yang dimiliki oleh kegiatan belajar sambil bermain dan dapat menarik perhatian dan memotivasi anak untuk belajar sehingga kreativitas anak meningkat. Anak - anak usia dini khususnya di PAUD Pelita Hidup Medan Denai juga masih memiliki daya kreativitas yang rendah. Hal ini dapat di lihat dari kegiatan anak sehari - hari, dimana masih menunggu pendidik, tidak mempunyai ide sendiri, belum bisa menungkapkan idenya sendiri kalau tidak dibantu oleh pendidik, anakanak masih tergantung dengan pendidik.

Bila dilihat secara langsung dari proses pembelajaran bahwa pada umumnya anak tidak semangat dalam mengikuti pelajaran, ini terlihat dari kebosanan anak yang hanya berdiam diri tanpa melakukan aktivitas yang bermakna untuk membuat situasi belajar lebih menyenangkan. Sedangkan jika dilihat dari pendidik di dalam mengajar sangat kurang menguasai materi, Page|53 perencanaan di dalam memulai pembelajaran belum terencana, kurang mengembangkan kreativitas dan latar belakang pendidikan bidangnya sehingga menyebabkan kurangnya strategi pendidik dalam mengembangkan media atau metode yang sesuai dengan kebutuhan anak, minimnya fasilitas (media pembelajaran) dan halaman bermain kurang luas sehingga anak tidak leluasa bermain, dimana alat permainannya masih kurang banyak sehingga kadang kala anak berebut bermain.

Rendahnya kreativitas pada anak di PAUD Pelita Hidup Medan Denai disebabkan oleh beberapa faktor, diantaranya Tutor di PAUD Pelita Hidup Medan Denai masih membutuhkan pelatihan mengenai pengembangan kreativitas anak sehingga anak didik lebih dapat bereksplorasi, bereksperimen, dan banyak mengajukan pertanyaan pada tutor ataupun oranglain. Hal ini yang menyebabkan kreativitas anak rendah adalah pembelajaran di PAUD Pelita Hidup Medan Denai yang masih memfokuskan pada kemampuan akademik seperti membaca, menulis, dan berhitung (Calistung). Hal ini disebabkan oleh tuntutan orangtua yang memandang bahwa hendaknya anak terlatih untuk membaca, menulis, dan berhitung.

Strategi pendidik dalam pembelajaran memiliki peranan penting dalam proses pengajaran untuk itu pendidik dalam menyampaikan materinya harus sesuai dengan metode atau teknik penyajian yang disampaikan dimana tutor harus mempunyai 
keterampilan dalam mengajar termasuk keterampilan membuka dan menutup pelajaran, keterampilan mengelola kelas di dalam mengajar dan mendidik anak didik selain pendidik juga harus mengetahui bagaimana menerapkan strategi mengajar yang baik. Pelaksanaan strategi yang sesuai dan keberhasilan yang diperoleh peserta didik ketika strategi tersebut diterapkan. Pengembangan kreativitas merupakan kemampuan seseorang untuk melahirkan suatu yang baru, baik berupa gagasan maupun karya yang nyata, baik dalam bentuk ciri - ciri berpikir kreatif maupun berpikir efektif, baik dalam karya baru maupun kombinasi dengan hal - hal yang sudah ada. Sehubungan pengembangan kreativitas dapat ditinjau aspek dari kreativitas yaitu : pribadi, pendorong, proses, produk yang menurut para ahli dapat membantu mengembangkan kreativitas anak.

\section{METODE PENELITIAN}

Dalam penelitian ini peneliti menggunakan jenis penelitian deskriptif dengan pendekatan kualitatif. Menurut Bog dan Taylor (1975 dalam Moleong 2007 : 4), pendekatan kualitatif merujuk kepada penelitian yang menghasilkan data deskriptif yang berupa kata - kata dan perilaku orang yang dapat diobservasi dari lisan maupun tulisan. Oleh sebab itu, peneliti memilih jenis penelitian ini karena pendekatan ini dianggap tepat.

Subjek penelitian atau informan adalah orang yang mampu memberikan informasi tentang situasi dan kondisi latar belakang penelitian (Lexy J. Moleong, 2007 : 132). Subjek dalam penelitian yang ada di PAUD Pelita Hidup Medan Denai terdiri dari 3 orang yaitu : Kepala Sekolah yang merangkap sebagai pendidik ada 1 orang dan yang hanya sebagai pendidik berjumlah 2 orang.

Dalam pengumpulan data yang dilakukan dengan kondisi yang alamiah, sumber data primer dan teknik pengumpulan data yang digunakan Page|54 berupa observasi, wawancara dan dokumentasi. Tanpa mengetahui teknik pengumpulan data maka peneliti akan mendapatkan data memenuhi standart data yang diterapkan. Sesuai dengan judul dan permasalahan yang saya lakukan, maka lokasi penelitian yang menjadi pilihan peneliti adalah di PAUD Pelita Hidup, Jln. A. R. Hakim Gang. Pendidikan No, 90 Medan Denai.

\section{HASIL DAN PEMBAHASAN}

Pendidikan Anak Usia Dini (PAUD) merupakan wahana pendidikan yang bertujuan untuk memberikan layanan pendidikan bagi anak usia o - 6 tahun dan melakukan berbagai rangsangan untuk membantu pertumbuhan dan perkembangan jasmani dan rohani agar memiliki kesiapan dalam memasuki jenjang Pendidikan Sekolah Dasar. Secara umum tujuan dari program PAUD adalah memberikan dukungan bagi kelangsungan hidup dan tumbuh kembangnya anak usia dini serta meningkatkan pengetahuan, dan kesadaran orangtua dan masyarakat akan pentingnya pendidikan bagi anak usia dini.

Pelaksanaan dari metode atau strategi diberbagai sekolah, baik untuk tenaga pendidikan formal maupun nonformal mempunyai cara pandangan dan penerapan menurut versi masing-masing pelaksana. Hal ini sebaiknya diperlakukan penyeragaman untuk efektivitas dalam rangka mengambangkan kreativitas anak. Khusus di PAUD Pelita Hidup Medan Denai, peneliti mengadakan penelitian. 
Untuk melihat sejauh mana pemahaman dan pelaksanaan strategi - strategi yang biasanya digunakan pendidik dalam mengembangkan kreativitas anak usia 4 5 tahun dan sebagai acuan dasar pelaksanaan proses pembelajaran mengajar. Maka peneliti menggunakan teknik pengumpulan data untuk memperoleh hasil penleitian yaitu : Hasil wawancara dari 3 pendidik sebagai subjek penelitian dijelskan bahwa penerapan strategi yang digunakan dalampembelajaran telah terlaksana dengan optimal walaupun dalam pelaksanaannya peserta didik tidak sepenuhnya memahami materi diajarkan pendidik dikarenakan strategi-strategi yang diajarkan pendidik masih bersifat sederhana dan kurang merangsang ketertarikan peserta didik untun berkreasi.

Dari hasil observasi dari 3 pendidik tersebut terdapat pandangan dan persepsi yang berbeda untuk itu sebaiknya dan harus, seperti uraian diadakan pelatihan dan pengembangan profesi kependidikan non formal khususnya pelatihan mengenai penggunaan strategi - strategi pembelajaran yang sesuai dengan kebutuhan dan minat peserta didik. Pelaksanaan penerapan strategi pendidik di PAUD Pelita Hidup Medan Denai dalam pengembangan kreativitas merujuk kepada cara mengajar pendidik dengan memahami dan mengusai startegi pembelajaran saat proses pembelajaran berlangsung. Peningkatan dan pengembangan ilmu pengetahuan tergantung pada kualitas dan tingkat pengetahuan pendidik dalam mengusai materi yang diajarkan.

Proses kegiatan pembelajaran dapat berjalan dengan baik apabila pendidik melakukan perencanaan sebelum mengajar, menguasai materi yang akan diajarkan dan adanya wawasan pendidik terhadappengembangan strategi-strategi yang sesuai dengan kebutuhan peserta didik. Pada waktu mengajar pendidik telah mampu membuat peserta didik dapat menyelasaikan tugas - tugas yang Page| 55 diberikan dan pelaksanaan startegi belajar telah diterapkan dengan baik walaupun lokasi dan waktunya kurang dalam proses pembelajaran. Secara umum penerapan strategi mengajar pendidik di PAUD Pelita Hidup Medan Denai untuk mengembangkan kretaivitas anak dan merupakan faktor utama yang mendukung lancarnya proses pembelajaran. Untuk itu pendidik harus menjalin kerjasama yang baik antara pendidik dan anak didik dan antara pendidik dengan orangtua sehingga penerapan strategi mengajar pendidik dapat terlaksana dengan baik.

Penerapan strategi mengajar pendidik dalam proses pembelajaran di PAUD Pelita Hidup Medan Denai, dilihat dari tahap penerapan pembelajaran, pelaksanaan pembelajaran dan hasil pembelajaran yaitu sebagai berikut : pendidik mengajar di dalam kelas ternyata melakukan strategi dalam pengajarannya, pendidik menyediakan buku-buku, media yang menarik yang mendukung proses pembelajaran peserta didik.

Pendidik juga mempersiapkan media sebelum pembelajaran dimulai. Pendidik juga memperhatikan prosedur pelaksanaan sesuai urutannya sebagai berikut : Pertama pendidik dengan tampilan memuaskan tujuan intruksional dengan sangat khusus dan kongkrit serta dengan membawa buku-buku yang mendukung pembelajaran. Kedua, pendidik mempersiapkan bahan ajar dan keterampilan pada anak.

Pelaksanaan penerapan strategi mengajar pendidik di PAUD Pelita Hidup 
Medan Denai dalam mengembangkan kreativitas anak didik merujuk kepada cara mengajar pendidik dengan teknik menguasai materi pembelajaran. Hal ini didasarkan pada kenyataan bahwa ini dari perubahan pembelajaran, pengembangan dan mutu dan pengetahuan pendidik tergantung pada kualitas dan tingkat kemampuan, dan itu semua dapat terwujud apabila strategi mengajar pendidik diterapkan dan dikembangkan dengan baik dalam proses kegiatan belajar mengajar.

\section{KESIMPULAN}

Pendidikan memegang peranan penting dalam segala aspek kehidupan terkecuali bagi mereka yang masih melanjutkan pendidikan kejenjang yang lebih tinggi tetapi hal yang lebih penting adalah bagaimana fondasi dasar pendidikan itu diterapkan pada anak usia dini. Pemilihan strategi dan pelaksanaan yang terarah demi terlaksananya tujuan pembelajaran yang diharapkan menjadi acuan terpenting bagi tenaga pendidik disegala pelaksaannya khususnya untuk anak usia dini.

Hal ini dikarenakan teman-teman yang berhasil dihimpun dilapangan masih sering dijumpai penggunaan staretgi yang tidak tepat sasaran demi terselenggaranya pencapaian tujuan pengajaran yang sesungguhnya kemampuan pendidik sebagai tenaga pendidik profesiaonal dituntut lebih memahami strategi strategi pengajaran. Beberapa strategi yang diterapkan dalam pelaksanaan kegiatan belajar mengajar, dalam hal ini dikhususkan bagi anak usia dini, strategi tersebut antara lain : strategi tantangan, sumber daya, kelompok kerja, dukungan dan bimbingan. Dalam penerapan kelima strategi mengajar pendidik sudah menciptakan lingkungan belajar yang kondusif. Pendidik telah menciptakan strategi yang menarik dan menyenangkan, walaupun dilihat dari kenyataan penggunaan masih dominan sederhana akan tetapi sudah mampu mengembangkan kreativitas anak.

\section{DAFTAR PUSTAKA}

Arikunto, Suharsimi. 2006. Metodologi Penelitian. Jakarta : Rineka Cipta.

Daryanto. 2010. Belajar dan Mengajar. Bandung: Yrama Widya.

Djamarah, Bahri. 2010. Jakarta : Rineka Cipta.

Hardini, Isriani. 2012. Strategi Pembelajaran Terpadu (Teori, konsep dan Implementasi). Yogyakarta : Familia (Group Relasi Inti Media).

Departemen Pendidikan dan Kebudayaan. 2013. Kamus Besar Bahasa Indonesia. Jakarta : Balai Pustaka.

Mansur. 2007. Pendidikan Anak Usia Dini Dalam Islam. Yogyakarta: Putaka Pelajar.

Masnipal. 2013. Siap Menjadi Guru dan Pengelola PAUD Profesional. Jakarta Gramedia.

Masitoh, dkk. 2005. Strategi Pembelajaran TK. Jakarta: Pusat Penerbitan Universitas Terbuka.

Moleong J, Lexy. 2007. Metode Penelitian Kualitatif. Bandung : Remaja Rosdakarya. 
Munandar, Utami. 1992. Pengembangan Kreativitas Anak Berbakat. Jakarta. Rineka Cipta.

Nasriah. 2005. Pendidikan Anak Usia Dini. Medan : Bahan Ajar PGTK FIP Unimed.

Patilima, Hamid. 2005. Metode Penelitian Kualitatif. Bandung : Alfabeta.

Peraturan Pemerintah No. 58 Tahun 2010. Tentang Standart Pendidikan Anak Usia Dini.

Rahmawati, Shinta (Ed). 20o1. Mencetak Anak Cerdas dan Kreatif. Jakarta : Kompas.

Rachmawati, Yeni dan Euis Kurniati. 2005. Strategi Pengembangan Kreativitas Pada Anak Usia Taman Kanak-kanak. Jakarta : Depdiknas.

Rachmawati, Yeni dan Euis Kurniati. 2011. Strategi Pengembangan Kreativitas Pada Anak Usia Taman Kanak-kanak. Jakarta : Prenada Media Group. RI. 2003. Undang-Undang RI No 20 Tahun 2003 Tentang Sistem PendidikanNasional. Jakarta : CV. Eka Jaya.

Roestiyah. 1991. Strategi Mengajar. Jakarta : Rineka Cipta.

Sanjaya,Wina. $\quad 2009 . \quad$ Strategi Pembelajaran Berorientasi Standar Proses Pendidikan. Jakarta : KencanaPrenada Media Group. Santi,

Danar. 2009. Pendidikan Anak Usia Dini antara Teori dan Praktek. Jakarta : Indek.
Satiadarma, Monty P. dan Fidelis E. Waruwu. 2003. Mendidik Kecerdasan. Jakarta : Pustaka Populer Obor.

Sihombing, U. 20oo. Pendidikan Luar Sekolah,Manajemen Strategi, Page | 57

Konsep,Kiat dan Pelaksanaan. Jakarta : P.D. Mahkota. Sudjana. 2006. Metode Statistik. Bandung : PT.

Rosdakarya. Sugiyono. 2007. Metode Penelitian Pendidikan Pendekatan Kuantitatif, Kualitatif, dan R \& D. Bandung: Alfabeta.

Supriadi, Dedi. (1994). Kreativitas, Kebudayaan dan Perkembangan IPTEK.Bandung : Alfabeta.

Suratno. 2005. Pengembangan Kreativitas Anak Usia Dini. Jakarta : Departemen Pendidikan Nasional.

Susanto, Ahmad. 2011. Perkembangan Anak Usia Dini. Jakarta : Departemen Pendidikan Nasional.

Yamin, Martimis dan Maisah. 2009. Manajemen Pembelajaran Kelas (Strategi Meningkatkan Mutu Pembelajaran). Jakarta : Gaung Persada Press.

\section{PROFIL SINGKAT}

Penulis pertama Anifah lahir di Medan, Sumatera Utara 6 September 1979. Pekerjaan saat ini sebagai Dosen Jurusan Pendidikan Masyarakat FIP Universitas Negeri Medan.

Penulis kedua Priscillia Octavia Marpaung, lahir di Parmonangan, Tapanuli utara, 14 Maret 1998. Menyelesaikan Pendidikan Sarjana Pendidikan Luar Sekolah di Fakultas Pendidikan, Universitas Negeri Medan pada tahun 2021. Pekerjaan saat ini sebagai Praktisi Pendidikan Masyarakat. 
Journal of Millennial Community, 3 (1), March 2021

Anifah,' Priscillia Octavia Marpaung, Vidya Dwi Amalia Zati

Penulis ketiga, Vidya Dwi Amalia Zati lahir di Medan, 13 Desember 1988. Menyelesaikan Pendidikan Magister pada prodi Linguistik Terapan Bahasa Inggris pada tahun 2014. Saat ini bekerja sebagai Dosen di jurusan Pendidikan Masyarakat Unimed 